\title{
Bologna Process in the Global Higher Education Arena. Going Digital?
}

\author{
Dominic Orr
}

\section{Introduction}

The Bologna Process has always been about seeing higher education within a national and a global context. This accounts for the 48 member countries of the European Higher Education Area (EHEA), which send their ministers responsible for higher education to the ministerial conferences every two to three years and send their high-level civil servants and national representatives into the many working group meetings. European-wide stakeholder membership organisations also play an important part in these processes. All of these actors bring in their own perspectives to the programme of the Bologna Process with regard to their own countries and institutions, the EHEA and the possible similarities and differences between the EHEA and third countries or other regions. This means that the Bologna Process has always been objectively international in its way of working ${ }^{1}$ and at least supported through digital communication processes, which facilitated the networks emerging out of these interactions.

Nevertheless, a big change within the two decades of the Bologna Process has been technological. In 1999, no-one had heard of a smartphone, and mobile phones, which enabled their owners to telephone with others on the move, were only just entering the mainstream. Today, in 2020, 'digital' has become a common attribute of descriptions of communication and production processes. Digitalisation in combination with globalisation is making the world figuratively 'spin faster', which brings opportunity and challenges for today's society. Moreover, one of the principles for what is being called the 'anthropocene curriculum' for higher education is to "rethink

\footnotetext{
${ }^{1}$ For a discussion of the normative values of the Bologna Process, please reference to the contribution in this volume entitled "The future of the EHEA-principles, challenges and ways forward".
}

D. Orr $(\bowtie)$

Kiron Open Higher Education, Berlin, Germany

e-mail: dominicjorr@gmail.com 
the implications of modern communication and information technologies for education and the architecture of the university." (Haus der Kulturen 2014b)

According to the Oxford Dictionary, digitisation stands for the conversion of text, pictures, or sound into a digital form that can be processed by a computer. This material process per se would not have a great impact. The Internet and digital networks are the means to connect disparate information, produce new data flows and structure new communication channels for more enriched interaction between people and processes (Castells 2010; Cerwal 2017). Digitisation must become embedded in larger systems ('ecosystems') that harness digital materials to lead to digital transformation (often called for short: digitalisation) (Brennen and Kreiss 2016). It can be said that digitalisation leads to changes in processes which accelerate the scale and intensify the scope of impact. For instance, the terms 'global' or 'international' are no longer restricted to processes which involve physical mobility, which in turn means that these experiences are open to more people. In sum, this means that harnessing new digital technologies is not simply a question of what technology can do, but how they interact with other established practices and routines of people and organisations.

In a commentary on whether the higher education scholar John Henry Newman, who published his famous book "The Idea of a University" in 1873 (Newman 1996), would support the idea of the digital university, George P Landow suggests that he would be most excited about the possibilities of hypertext for knowledge formation (Landow 1996). This technique, which is today so embedded in our digital lives we hardly think about it, facilitates infinite links between disciplinary knowledge and multiple sources of information. According to Landow, Newmann saw true education as "the recognition that every subject, every science, every discipline, exists as part of a network of interrelations" (ibid).

Higher education is both affected by the environment it works in and can have effects on the world around it. In a study for the British government, Ron Barnett describes this relationship between higher education and its environment as a sort of flexibility, where higher education seeks a connection and aims for responsiveness to the outside world. He states: "In a fluid, dynamic and global world, higher education systems cannot but exhibit flexibility and it is right that they should do so." (Barnett 2014) But he also warns that higher education must also be committed to standing up for academic values, truth, and provide an education for global citizens capable and willing to improve society (Barnett 2011). It should maintain a critical link to the outside with some temporal and conceptual distance.

The risks of a focus on digitalisation, without reviewing and rejuvenating the idea of higher education in a digital world, are that this will simply lead to more extreme versions of developments, which are already observed within some parts of higher education. There has been stark criticism that past reforms in higher education according to the new public management paradigm have been based on an administrative understanding of higher education (Dougherty and Natow 2015; Stahlke and Nyce 1996). In this vein, Johnston et al. argue that a version of digitalisation of higher education, that simply focuses on everything being even more measurable than before, will likely lead to strengthening the neoliberal concept of a fully utilitarian version of higher education (Jensen et al. 2018). 
The first hype around digital education a decade ago followed this type of vision in discussions on the uses and values of MOOCs (massive open online courses). It was all about providing access to knowledge for all but focussed much less on providing learning environments of a high pedagogical value using digital technologies (Margaryan et al. 2014); although learners and teachers did benefit in diverse ways (Krause and Lowe 2014). This view was likely further amplified by the disruptive paradigm that many promoters of the possible impact of digitalisation emphasised so heavily in the last ten years. They followed what Martin Weller had called the "silicon valley approach" (Weller 2015) of "moving fast and breaking things", as the famous slogan of one social media company goes.

So, a review of how higher education might benefit from the opportunities and possibilities provided by digitalisation will have to start out from a question of what the main goals for higher education should be. This is opportune at a moment, where the Bologna Process has run for two decades, since perhaps some of the mechanisms and ways of doing things developed over the past years are less fit for purpose than they were. An example of this argument is provided by Dominic Orr and Alex Usher, who analyse performance-based funding mechanisms to uncover how these often define student success in a very specific normative way, e.g. the successful student (and by implication: the high performing university) is the one that achieves graduation of a full academic programme within the prescribed time (Orr and Usher 2018). Thus performance-based funding is working as a normative mechanism which leaves little incentive for more flexible ways of organising courses of study in higher education.

This chapter will look at three major spheres of action that together determine how higher education works in and interrelates to society in the digital age. It will investigate the current challenges in each of these spheres and sketch possible responses of higher education and how research in the context of the Bologna Process might help to explore and test these responses.

\section{Higher Education in the Context of Labour Market Demands and New Skills}

Participation in higher education has grown dramatically in the last two decades (European Commission/EACEA/Eurydice 2018). This is one of the main reasons that higher education's relationship to the labour market has become such a key reference point. The Sorbonne Declaration, right at the start of the Bologna Process, highlighted the importance of paying heed to developments in the labour market:

We are heading for a period of major change in education and working conditions, to a diversification of courses of professional careers with education and training throughout life becoming a clear obligation. We owe our students, and our society at large, a higher education system in which they are given the best opportunities to seek and find their own area of excellence. (Sorbonne Declaration - Joint declaration on harmonisation of the architecture of the European higher education system 1998) 
In the current setting, this description has become even more appropriate. We can expect labour markets in industrialised countries to change dramatically in the next decade. The task combinations required by most people's jobs will change and diversify as routine and predictable tasks are increasingly being automated. One OECD study has shown that the effects are already becoming visible with over one-third of variance in the occupational unemployment rate attributed to automatability of the common tasks by occupation (Nedelkoska and Quintini 2018).

Future business growth in developed economies is expected to be reliant on smart services and smart products (Hüther 2016). Both are examples of extending the value-added through additional services which increase the complexity of the value chain and are likely to be reliant on high-skilled labour. This shift will require closer interactions between computers and humans in order to augment task execution in production and service delivery. It will also lead to people's jobs consisting of a higher share of non-routine, creative and communicative tasks (Davenport and Kirby 2016).

Next to these changes, knowledge and skills fields, citizens of a digital society will need to acquire the knowledge and competencies which enable them to harness the benefits of digital technologies and be aware of their pitfalls. This set of skills is often termed 'digital literacy' or 'computational thinking' (Park 2019; Working Group on Education 2017). Accompanying this development will be new jobs which are more specialist (such as big data analysts, robotic developers etc.), where incumbents will need a balanced set of technical, anthropological and ethical skills to enable them to work on welfare-increasing usage of these technologies (Stifterverband and McKinsey and Company 2019).

In all cases, the evidence shows that broader profiles will be required of new candidates at the start of their employment. Higher education offers students the opportunity to develop so-called transferable skills or soft skills, including problemsolving, communication, teamwork and learning. This gives university graduates - at least implicitly - the skills and competencies necessary for success in a digital and an interconnected world. However, an analysis published on the basis of European data (Cedefop 2018) showed that young graduates self-assess their preparedness for their first job negatively, with more than one-fifth feeling underqualified. The highest proportions of this type of "under-skilling" can be found in the fields of medicine and agriculture. The authors of the study assume that this can be explained by a constantly changing qualification context due to the further development of new technologies, working methods and techniques. Another study, based on the same data set, found that it is not the lack of standard knowledge for these specific areas but soft skills, such as better communication skills with patients and teamwork (Livanos and Nunez 2015).

In an innovative environment, it is furthermore likely that learning curves will be repeated as workplaces are reorganised, and practices changed to make best use of digital opportunities through a person's career (Bessen 2015). Moreover, the expectation for increased frequency of innovation and change in task combinations lead to predictions that large shares of the population in developed countries will have bumpy career pathways, which require frequent periods of reorientation and retrain- 
ing (Manyika et al. 2017). This all requires a review of how higher education can embed lifelong learning into our societies.

These are not new challenges for higher education, as the key concepts such as relevance, skills mismatch, lifelong learning and even digital literacy suggest. But they receive a new quality in a digital world precisely because of the extension of learning and workspace through digital environments. Jöran Muuß-Merholz argues that we should start out by thinking of our life-world as consisting of two parts to make the whole, in the same way a penguin lives in the 'green world' on land i.e. here the physical world) and the 'blue world' of the ocean (i.e. here the digital world) (Muuß-Merholz 2019). Citizens should learn to be equally agile in both spaces and utilise the full benefits of each of them. Indeed, the 'learning world' of the student probably doesn't even differentiate between these two spheres. But many learning programmes only focus on one of these (ibid).

Therefore, the question is what could be done to take on these challenges? The contributions in this book section provide some insights here. A first key question is how to include the 'digital world' into students' curricula. In the case of Enrique Planells-Artigot and Santiago Moll-Lopez (in this volume), the challenge was to find a way to extend internationalisation in the curriculum for student groups who would ordinarily not meet. They hoped that this would enable diverse real-life collaborative activities in higher education for the students from two business schools-one in Spain, one in South Korea-as a way to learn the required skills in a professional context. To achieve this aim, the authors established virtual teams of exchange between the students. Inter alia, in hindsight, the authors found that such a constellation of virtual exchange did indeed help students to develop intercultural and team-building skills, but also led to further challenges of how to organise the virtual learning space. For instance, students were asked to use the tool MS-Teams for exchange, but many of them actually used Facebook, which they were more familiar with. This experience can actually be described through the lens of David White and Alison le Cornu's concept of "digital residency" (White \& Le Cornu 2011). This states that 'visitors' simply use a certain digital tool to fulfil a task here: as required by their instructors), whereas they might see themselves as "residents" in another digital space here: Facebook). This insight highlights the new pedagogical ways of thinking that must accompany the use of new technologies to build up skills and competencies.

This challenge is, in fact, the starting point of the approach of Andrew Whitechurch (in this volume). He starts out from the perspective of a person being prepared for life in the informational abundance of the digital world-through pedagogical exposure to this world. He argues that people navigate the abundance of information around them by creating their own "information landscapes". It is the task of higher education to reflect on how they do this and to provide students with support in gaining confidence and certainty in this process. For this, he describes a pedagogical model which introduces and supports students in their discovery and reflection on their own ways of navigation using digital tools, search and curation strategies. He defines the role of the teacher (or indeed: better experienced and knowledgeable peers) in this as "stewarding" (Wenger et al. 2009). 
These two practice examples highlight the ways forward in this area for teaching and learning practice in the EHEA. Reaching the potential given by digitalisation for teaching and learning means adopting new pedagogical methods. These should follow the didactical concepts of widening the learning space to include the learners' own spaces, as reflected in the concepts of Rosemary Luckin (2010), Jan Herrington et al. (2010) and David White (White \& Le Cornu 2011), bearing in mind recent research that such concepts only work if the learner perspective and their contribution to the learning space is taken seriously (Chiu et al. 2018). More work is required here.

\section{Higher Education in the Context of Grand Challenges and Ethical Concerns}

Learning is not simply about achieving smoother transition and success in the labour market, but also about contributing to the transformation of society for the good of all. The United Nations Sustainable Development Goals (SDGs) cover social and economic development issues including poverty, hunger, health, education, global warming, gender equality, water, sanitation, energy, urbanization, environment and social justice. The Paris Communique emphasised the ministers' commitment to this challenge:

\footnotetext{
We commit to developing the role of higher education in securing a sustainable future for our planet and our societies and to finding ways in which we, as EHEA Ministers, can contribute to meeting the United Nations Sustainable Development Goals at global, European and national levels. (Paris communiqué 2018)
}

But taking these goals seriously also requires changes to how higher education is organised and activities configured. The so-called 'grand challenges' present a challenge to science, which is typically organised along disciplinary boundaries. Raising people out of poverty, for instance, is about taking a global view on how food provision, health, education and the labour market work together to explore situations, which may have positive or negative effects on poverty. Here, digitalisation might be starting to provide a dividend for all parts of the population or cementing a greater social divide. Research and development must be creative, interdisciplinary and intercultural in its search for solutions. An analysis of articles published in the academic journal Nature over the past 110 years does indeed show that interdisciplinarity has been increasing in science overall, with the authors stating: "No longer are the scientific disciplines being siloed off from each other." (Thomsen 2019)

However, other analyses are less positive. An analysis of how climate change has been analysed by the Intergovernmental Panel on Climate Change (IPCC) showed prominence of quantitative sciences from natural science and economics, with little integration of issues related to the humanities. Mike Hulme states in conclusion: "The view of climate change thus constructed by the IPCC (...) is heavily one-sided. 
(...) [T] he analysis of anthropogenic climate change continues to be dominated by positivist disciplines at the expense of interpretative ones." (Hulme 2011).

Further challenges emerge out of research and development itself. Digitalisation is making some developments easier or more sophisticated than ever before. For instance, where molecular biology is focussed on modifying the genes or behavioural patterns of insects to solve one technical problem (e.g. reduce the need for pesticide in agriculture), the ethical question of the knock-on effects for other parts of the ecosystem must be examined. The fields of [ethics + scientific field] are not new, but their importance is growing with the new possibilities for experimentation and adaptation made available through digitalisation. One central focus is the ethical consequences of Artificial Intelligence. This particular challenge is being taken seriously internationally, with the Asilomar AI Principles from the Future of Life Institute, which have already been endorsed by over four thousand academics from across the world. Still, more work is needed here. As a recent UNESCO publication states: "While research is moving full speed ahead on the technical side of AI, not much headway has been made on the ethical front." (UNESCO 2018) It remains a fundamental challenge to ensure that all parts of society are aware of the ethical considerations, which go along with digital progress. The challenge here is, as one article states, that "While technology moves at exponential rates, social policies and values systems tend not to." (Damm and Haan 2016)

Of course, there have been some ambitious projects, which aim to provide a comprehensive view on this, thereby setting out a foundation from which research activities and teaching and learning can be developed. One of these has been an interdisciplinary collaboration initiated by the German Haus der Kulturen der Welt (Berlin) and the Max Planck Institute for the History of Science (Berlin), which brought together around forty scholars from around the world, working in the natural, environmental, and social sciences, as well as the humanities, arts, and architecture. These academics jointly developed an "Anthropocene Curriculum" as a collaborative and ongoing project (Haus der Kulturen 2014a). Of particular note to this chapter is the work they did on the "technosphere", a term they use to describe the technical mobilization and hybridization of energy, materials, and environments into a planetary system comparable in scale and function to the biosphere or hydrosphere. The project asked: "But where is that ominous technosphere to be found? How does it operate? What impact will it have on the everyday concerns of humans and their experiences? And how did we all end up in this world of technological vertigo?" (ibid).

In this anthropocene world, humanities play an important role in always refocussing on the question of what role humans can and do play. The contribution from Mădălina Chitez, Roxana Rogobete and Alexandru Foitoş (in this volume) looks at the need to establish centres for digital humanities and describes the case of one university. According to Wikipedia, digital humanities can be defined as "an area of scholarly activity at the intersection of computing or digital technologies and the disciplines of the humanities. It includes the systematic use of digital resources in the humanities, as well as the analysis of their application. (...) It brings digital tools and methods to the study of the humanities with the recognition that the printed 
word is no longer the main medium for knowledge production and distribution." 2 The authors argue that a central goal of centres for digital humanities should be to ensure a cross-over between disciplines. Quoting Opel et al., they state that it should serve "as a space of contact for graduate students from the humanities and STEM disciplines who are approaching issues of shared concern." (Opel and Simeone 2019)

These references point to the need to find common projects, which encourage students and researchers from different disciplines and therefore, necessarily, different ways of seeing, to work together. This is the only way to move forward on ensuring that higher education can contribute to a better world. Technology is here both object of study, but also facilitator of interconnections and collaboration between these groups, as also shown by the example of the living "Anthropocene Curriculum". Such processes must be enabled and encouraged through policy and practice, and it is to these topics that we proceed in the subsequent section.

\section{Higher Education and Strategy Development}

Since the beginning of the 1990s as part of new governance concepts, universities are expected to sharpen their own profiles, and digitalisation presents a new opportunity for this (Orr et al. 2019; Schmid and Baeßler 2016). In the context of the development of the EHEA, the Paris Communique formulated a call to action, which requires initiatives on the part of individual higher education institutions and policy-makers to realise:

\footnotetext{
Digitalization plays a role in all areas of society and we recognize its potential to transform how higher education is delivered and how people learn at different stages of their lives. We call on our higher education institutions to prepare their students and support their teachers to act creatively in a digitalized environment. (Paris communiqué 2018)
}

Indeed, a survey of higher education institutions carried out by the International Association of Universities found that two-thirds of responding institutions from across the world saw digital transformation as a high priority (Jensen 2019). Similar results can be found within the EHEA. According to the Trends survey from the European University Association, around half of all responding universities and colleges affirmed that digital learning was "becoming part of the institutional strategy" and just under half affirmed that digital learning was now being used more strategically (Gaebel and Zhang 2018).

However, the university is a special organizational form with several levels of responsibility that are only loosely linked (Kogan and Becher 1980). This has given the institution the capability to maintain overall stability, while on some levels being innovative; a characteristic especially vital for carrying out groundbreaking research and development and being a hub for ideas on societal reform. However, as institutions try to find ways to balance internal stability with unstable (changing) demands

\footnotetext{
${ }^{2}$ https://en.wikipedia.org/wiki/Digital_humanities.
} 
from their environment, it also makes coherent strategy difficult (Jongbloed 2015; Stensaker and Benner 2013).

In their book entitled "Organisational Strategy Structure and Process", Miles and Snow proposed a new way of seeing organisational design (Miles and Snow 1978; Sollosy et al. 2015). They argued that organisations must undertake an ongoing process of alignment to their environment, and failure to do so makes organisations ineffective. Adjusting to environmental dynamics is a complex process involving change and development of a myriad of internal activities. Moreover, Miles and Snow offered a conceptual model for recognising the fundamental focus of organisations and classifying them into one of four basic business strategy models—prospector, defender, analyser and reactor, with the first two being the two extremes on a continuum. Their approach has been applied to analysing many organisations across the world (Orr et al. 2019). The book was first published in 1978 but was recently republished to celebrate its 25-year anniversary and to discuss its continued relevance in the field of organisation design.

The authors break down the adaptive cycle into three main strategic problems:

- The entrepreneurial problem is focussed on which product or service should be chosen to reach which target market.

- The engineering problem is about creating a system and choosing technologies to transform the entrepreneurial idea into a concrete product or service.

- The administrative problem is, finally, about reducing uncertainty within the organisation by setting up routines to rationalise and stabilise activities and decisionmaking.

Within this framework, the most innovative organisations are classified as 'Prospectors' by the authors. These organisations are constantly searching for new markets and new growth opportunities while encouraging organisation-wide change and risk-taking. They follow a 'first-in' strategy for market entry or market innovation. Today, they might be classified as organisations with a start-up mindset.

The counterpart to this organisational type is the 'Defender', which concentrates on protecting its current markets, maintaining stable growth, and serving its current customers. It aims to improve efficiency and cost-effectiveness and so is largely focussed on engineering and administrative problems. It appears that many HEIs are currently following this strategy in the context of digitalisation. This fact may explain a central finding from a German study on digitalisation in higher education. According to a study by Gilch et al., although $44 \%$ of the surveyed representatives of German universities rate the significance of digitalisation for their institution as 'high', none rate the overall level of realised digitalisation as 'high', and only a fifth of these universities rate it as 'quite high' (Gilch et al. 2019). It would seem beneficial for HEIs to think in strategy more like a start-up and follow the 'Prospector' approach. As argued in the introduction, this means starting out from the needs of higher education students (Orr et al. 2019).

Gabriela Grosseck, Laura Malia and Mădălin Bunoiu recount the story of developments at the West University of Timişoara, Romania (in this volume). They see the 
goal of a new strategy for digital transformation in their institution to be adopting a new mindset which embraces digitalisation and innovation on all levels of the organisation. As a basis for their strategic development, the authors started with a survey of students and found that "more than half of the students surveyed expect a change, a disruption in the university model within the next 2-3 years." (ibid) They conclude their paper with a cautious evaluation that this transformation will be a difficult journey, requiring collective actions of different people (academics, administrators) and changes to common processes within their university.

Higher education policy can play a role in helping institutions achieve this change. Policy is always about transferring policy ideas into practice using incentives, regulations and information campaigns (Bemelmans-Videc et al. 1998). Dominic Orr, Florian Rampelt and Alexander Knoth aim to support the development of strategy and policy through the White Paper entitled "Bologna Digital" described in their chapter (in this volume). They start out by recognising the twin issues that: (i) digitalisation has been a hot topic in policy and the media for the last few years, but (ii) that digital transformation does not per se specify what type of goals it is ultimately following - aside from the "adoption" of technologies. That is to say that digital transformation neither answers the 'why' nor the 'how' question-i.e. how this "transformation" will happen. To this aim, and with reference to policy theory, the authors conjectured that reducing goal conflict (i.e. defining 'why') and reducing practice ambiguity (i.e. defining 'how') would help to facilitate a more integrative digital policy and practice. Their White Paper aligns the goals of the Bologna Process to the potential of digitalisation and mentions good practices from across Europe. But it should be noted that this is a largely normative instrument that they are using. It should be backed up and expanded on through future research critically examining the why and how questions.

Overall, then, we should note that thinking about digitalisation in the context of the Bologna Process only leads us back to the old questions of how higher education can efficiently and effectively prepare new generations for a fair and sustainable future through learning opportunities, academic exchange, research and development. The affordances of connectivity, networking and better links between knowledge domains are the benefits that new technologies can contribute to solving these challenges. Future institutional strategies and policies should aim to harness these, while ensuring that research accompanying new initiatives facilitates learning from good and bad experiences within the EHEA and beyond.

\section{References}

Barnett, R. (2011). The coming of the ecological university. Oxford Review of Education, 37(4), 439-455. https://doi.org/10.1080/03054985.2011.595550

Barnett, R. (2014). Conditions of flexibility - Securing a more responsive higher education system. Higher Education Academy. https://www.heacademy.ac.uk/sites/default/files/resources/fp_ conditions_of_flexibility_0.pdf 
Bemelmans-Videc, M.-L., Rist, R. C., \& Vedung, E. (Eds.). (1998). Carrots, Sticks, and Sermons: Policy Instruments and Their Evaluation (p. 280). Transaction Publishers.

Bessen, J. (2015). Learning by Doing: The Real Connection between Innovation, Wages, and Wealth. Yale University Press.

Brennen, J. S., \& Kreiss, D. (2016). Digitalization. In The International Encyclopedia of Communication Theory and Philosophy (pp. 1-11). John Wiley \& Sons, Inc. https://doi.org/10.1002/ 9781118766804.wbiect111

Castells, M. (2010). The Rise of the Network Society. Blackwell Publishing. https://doi.org/10.2307/ 1252090

Cedefop. (2018). Insights into skill shortages and skill mismatch (pp. 1-108). Publications Office of the European Union. https://doi.org/10.2801/645011

Cerwal, P. (Ed.). (2017). Ericsson Mobility Report. https://www.ericsson.com/assets/local/ mobility-report/documents/2017/ericsson-mobility-report-june-2017.pdf

Chiu, P.-S., Pu, Y.-H., Kao, C.-C., Wu, T.-T., \& Huang, Y.-M. (2018). An authentic learning based evaluation method for mobile learning in Higher Education. Innovations in Education and Teaching International, 55(3), 336-347. https://doi.org/10.1080/14703297.2017.1417147

Damm, D., \& Haan, N. (2016). Solutions to Humanity's Global Grand Challenges Are Within Our Reach. https://medium.com/singularityu/solutions-to-humanitys-global-grand-challengesare-within-our-reach-79292efa888e

Davenport, T. H., \& Kirby, J. J. (2016). Only humans need apply: winners and losers in the age of smart machines (p. 276). Harpers Business.

Dougherty, K. J., \& Natow, R. S. (2015). The Politics of Performance Funding for Higher Education: Origins, Discontinuations, and Transformations. Johns Hopkins University Press.

European Commission/EACEA/Eurydice. (2018). The European higher education area in 2018: Bologna Process implementation report. Publications Office of the European Union. https://doi. org/10.2797/63509

Gaebel, M., \& Zhang, T. (2018). Trends 2018 - Learning and teaching in the European Higher Education Area. European University Association.

Gilch, H., Beise, A. S., Krempkow, R., Müller, M., Stratmann, F., \& Wannemacher, K. (2019). Digitalisierung der Hochschulen - Ergebnisse einer Schwerpunktstudie für die Expertenkommission Forschung und Innovation (No. 12). Expertenkommission Forschung und Innovation. https:// www.e-fi.de/fileadmin/Innovationsstudien_2019/StuDIS_14_2019.pdf

Haus der Kulturen. (2014a). Anthropocene Curriculum. HKW; Haus der Kulturen der Welt. https://www.hkw.de/en/programm/projekte/2014/anthropozaen_curriculum/anthropozaen_ curriculum_1.php

Haus der Kulturen. (2014b). Teaching the Anthropocene from a Global Perspective. HKW; Haus der Kulturen der Welt. https://www.hkw.de/en/programm/projekte/2014/anthropocene_campus/ background_making_of/background_making_of_teaching_anthropocene.php

Herrington, J., Reeves, T. C., \& Oliver, R. (2010). A Guide to Authentic e-Learning. Routledge. https://www.routledge.com/A-Guide-to-Authentic-e-Learning-1st-Edition/HerringtonReeves-Oliver/p/book/9780415998000

Hulme, M. (2011). Meet the humanities. Nature Climate Change, 1(4), 177-179. https://doi.org/ $10.1038 /$ nclimate 1150

Hüther, M. (2016). Digitalisation: An engine for structural change - A challenge for economic policy. Cologne Institute for Economic Research (IW).

Jensen, T. (2019). Higher Education in the Digital Era - The current state of transformation around the world. International Association of Universities. https://iau-aiu.net/IMG/pdf/technology_ report_2019.pdf

Johnston, B., MacNeill, S., \& Smyth, K. (2018). Neoliberalism and the Digital University: The Political Economy of Learning in the Twenty-First Century. In B. Johnston, S. MacNeill, \& K. Smyth (Eds.), Conceptualising the Digital University: The Intersection of Policy, Pedagogy and Practice (pp. 3-17). Springer International Publishing. https://doi.org/10.1007/978-3-31999160-3_1 
Jongbloed, B. (2015). Universities as hybrid organizations: Trends, drivers, and challenges for the European university. International Review of Public Administration, 45(3), 207-225. https://doi. org/10.1080/00208825.2015.1006027

Kogan, M., \& Becher, T. (1980). Process and structure in higher education. Ashgate Publishing.

Krause, S. D., \& Lowe, C. (Eds.). (2014). Invasion of the MOOCs: The promises and perils of massive open online courses. Parlor Press.

Landow, G. P. (1996). Newman and the Idea of an Electronic University. In F. M. Turner (Ed.), The Idea of a University (pp. 339-362). Yale University Press.

Livanos, I., \& Nunez, I. (2015). Rethinking under-skilling: evidence from the first Cedefop European Skills and Jobs Survey. CEDEFOP/IZA Workshop on Skills and Skill Mismatch. http:// conference.iza.org/conference_files/2015_Skill_Mismatch/livanos_i5629.pdf

Luckin, R. (2010). Re-Designing Learning Contexts: Technology-Rich, Learner-Centred Ecologies. Routledge. https://www.routledge.com/Re-Designing-Learning-Contexts-TechnologyRich-Learner-Centred-Ecologies/Luckin/p/book/9780415554428

Manyika, J., Lund, S., Michael, C., Bughin, J., Woetzel, J., Batra, P., Ko, R., \& Sanghvi, S. (2017). Jobs Lost, Jobs Gained: Workforce Transitions in a Time of Automation (p. 160). McKinsey Global Institute. https://www.mckinsey.com/ /media/McKinsey/GlobalThemes/ FutureofOrganizations/Whatthefutureofworkwillmeanforjobsskillsandwages/MGI-Jobs-LostJobs-Gained-Report-December-6-2017.ashx

Margaryan, A., Bianco, M., \& Littlejohn, A. (2014). Instructional Quality of Massive Open Online Courses (MOOCs). Computers \& Education, 80, 77-83. https://doi.org/10.1016/j.compedu. 2014.08.005

Miles, R. E., \& Snow, C. C. (1978). Organizational Strategy, Structure, and Process. McGraw-Hill.

Muuß-Merholz, J. (2019, June 26). Der große Verstärker. Spaltet die Digitalisierung die Bildungswelt? - Essay APuZ. Bpb.de; Bundeszentrale für politische Bildung. https://www.bpb.de/ apuz/293120/der-grosse-verstaerker-spaltet-die-digitalisierung-die-bildungswelt

Nedelkoska, L., \& Quintini, G. (2018). Automation, skills use and training (Issue 202). OECD. https://doi.org/10.1787/2e2f4eea-en

Newman, J. H. (1996). The Idea of a University (Rethinking the Western Tradition) (F. M. Turner (Ed.)). Yale University Press.

Opel, D., \& Simeone, M. (2019). The Invisible Work of the Digital Humanities Lab: Preparing Graduate Students for Emergent Intellectual and Professional Work. Digital Humanities Quarterly, 13(2). http://www.digitalhumanities.org/dhq/vol/13/2/000421/000421.html

Orr, D., Lübcke, M., Schmidt, P., Ebner, M., Wannemacher, K., Ebner, M., \& Dohmen, D. (2019). AHEAD Internationales Horizon-Scanning: Trendanalyse zu einer Hochschullandschaft in 2030. Hochschulforum Digitalisierung. https://hochschulforumdigitalisierung.de/sites/ default/files/dateien/HFD_AP_Nr_42_AHEAD_WEB.pdf

Orr, D., \& Usher, A. (2018). Revisiting student performance as a cornerstone of higher education how is student performance reflected in performance-based funding? In E. Hazelkorn, H. Coates, \& A. C. McCormick (Eds.), Research Handbook on Quality, Performance and Accountability in Higher Education. Springer.

Orr, D., Weller, M., \& Farrow, R. (2019). How is Digitalisation Affecting the Flexibility and Openness of Higher Education Provision? Results of a Global Survey Using a New Conceptual Model. Journal of Interactive Media in Education, 2019(1), 3. https://doi.org/10.5334/jime.523

Paris communiqué. (2018). Bologna Process. http://www.ehea2018.paris/Data/ElFinder/s2/ Communique/EHEAParis2018-Communique-final.pdf

Park, Y. (2019). Digital Intelligence - DQ Global Standards Report 2019. DQ Institute. https:// www.dqinstitute.org/wp-content/uploads/2019/03/DQGlobalStandardsReport2019.pdf

Schmid, U., \& Baeßler, B. (2016). Strategieoptionen für Hochschulen im Digitalen Zeitalter (No. 29). Hochschulforum Digitalisierung. https://hochschulforumdigitalisierung.de/sites/default/ files/dateien/HFD_AP_Nr29_Strategieoptionen_fuer_Hochschulen_im_digitalen_Zeitalter.pdf 
Sollosy, M., Guidice, R. M., \& Parboteeah, K. P. (2015).A Contemporary Examination OfThe Miles and Snow Strategic Typology Through The Lens Of Ambidexterity Vol. 2015, pp. 11213-11213. https://doi.org/10.5465/AMBPP.2015.11213abstract

Sorbonne Declaration - Joint declaration on harmonisation of the architecture of the European higher education system. (1998). Sorbonne Declaration. http://www.ehea.info/media.ehea.info/ file/1998_Sorbonne/61/2/1998_Sorbonne_Declaration_English_552612.pdf

Stahlke, H. F. W., \& Nyce, J. M. (1996). Reengineering Higher Education: Reinventing Teaching and Learning. CAUSE/EFFECT, 19(4), 44-51.

Stensaker, B., \& Benner, M. (2013). Doomed to be Entrepreneurial: Institutional Transformation or Institutional Lock-Ins of 'New' Universities? Minerva, 51(4), 399-416. https://doi.org/10.1007/ s11024-013-9238-6

Stifterverband, \& McKinsey and Company. (2019). Hochschulbildungsreport 2020 - Für morgen befähigen. Jahresbericht 2019. Stifterverband für die Deutsche Wissenschaft e. V. http://www. hochschulbildungsreport2020.de/download/file/fid/163

Thomsen, I. (2019). A cosmic data visualization celebrates science journal Nature's 150-year anniversary. https://news.northeastern.edu/2019/11/13/a-cosmic-data-visualization-celebratesscience-journal-natures-150-year-anniversary/

UNESCO. (2018). Artificial Intelligence. UNESCO. http://unesdoc.unesco.org/images/0026/ 002652/265211e.pdf

Weller, M. (2015). MOOCs and The Silicon Valley Narrative. Journal of Interactive Media in Education, 1(5), 1-7. https://doi.org/10.5334/jime.am

Wenger, E., White, N., \& Smith, J. D. (2009). Digital Habitats: Stewarding Technology for Communities. CPsquare. http://technologyforcommunities.com/wp-content/uploads/2016/12/ digitalhabitatsactionnotebook.pdf

White, D. S., \& Le Cornu, A. (2011). Visitors and Residents: A new typology for online engagement. First Monday, 16(9). https://firstmonday.org/ojs/index.php/fm/article/view/3171/3049

Working Group on Education. (2017). Digital skills for life and work. Broadband Commission for Sustainable Development. http://broadbandcommission.org/Documents/publications/WGEducation-Report2017.pdf

Open Access This chapter is licensed under the terms of the Creative Commons Attribution 4.0 International License (http://creativecommons.org/licenses/by/4.0/), which permits use, sharing, adaptation, distribution and reproduction in any medium or format, as long as you give appropriate credit to the original author(s) and the source, provide a link to the Creative Commons license and indicate if changes were made.

The images or other third party material in this chapter are included in the chapter's Creative Commons license, unless indicated otherwise in a credit line to the material. If material is not included in the chapter's Creative Commons license and your intended use is not permitted by statutory regulation or exceeds the permitted use, you will need to obtain permission directly from the copyright holder.

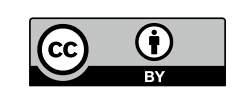

